\title{
Modification of Lipid Profile in Commercial Cow Milk Samples before and after Their Expiration Date: Evaluation of Storage Crucial Parameters and Possible Environmentally Friendly Disposal Alternatives
}

\author{
Eduardo Sommella, ${ }^{1,2}$ Manuela Giovanna Basilicata, ${ }^{1,3}$ Gian Carlo Tenore ${ }^{(D)}$, \\ Michele Manfra, ${ }^{5}$ Raffaella Mastrocinque, ${ }^{1,2}$ Carmine Ostacolo, ${ }^{4}$ Andrea Vitale, ${ }^{6}$ \\ Marcello Chieppa $\mathbb{D}^{1,7}$ Pietro Campiglia, ${ }^{1,2}$ and Giacomo Pepe $\mathbb{D}^{1,6}$ \\ ${ }^{1}$ Department of Pharmacy, School of Pharmacy, University of Salerno, Via Giovanni Paolo II 132, 84084 Fisciano, Italy \\ ${ }^{2}$ European Biomedical Research Institute of Salerno, Via De Renzi 50, 84125 Salerno, Italy \\ ${ }^{3}$ PhD Program in Drug Discovery and Development, University of Salerno, Via Giovanni Paolo II 132, 84084 Fisciano, Italy \\ ${ }^{4}$ Department of Pharmacy, University of Naples Federico II, Via D. Montesano 49, 80131 Napoli, Italy \\ ${ }^{5}$ Department of Science, University of Basilicata, Viale dell'Ateneo Lucano 10, 85100 Potenza, Italy \\ ${ }^{6}$ Pineta Grande Hospital, Via Domitiana, 81130 Castel Volturno, Italy \\ ${ }^{7}$ National Institute of Gastroenterology "S. de Bellis", Institute of Research, 70013 Castellana Grotte, Italy
}

Correspondence should be addressed to Giacomo Pepe; gipepe@unisa.it

Received 23 November 2017; Accepted 25 January 2018; Published 21 February 2018

Academic Editor: Efstathios Giaouris

Copyright (C) 2018 Eduardo Sommella et al. This is an open access article distributed under the Creative Commons Attribution License, which permits unrestricted use, distribution, and reproduction in any medium, provided the original work is properly cited.

\begin{abstract}
Milk waste is considered a highly polluting material and its disposal is an economic and environmental problem for the dairy sector. Despite this, it can be turned into a source of nutraceutical products and biodiesel substrate. The objective of this study was to determine the qualitative and quantitative variation of single fatty acids in cow milk samples before expiration date and within 28 days after expiration date in order to monitor how the profile of the lipid fraction is influenced by different physicochemical parameters. It was shown that lipolysis in milk is a process independent of time but dependent on the values of $\mathrm{pH}$ and total titratable acidity, while crucial parameters for the lipid oxidation are temperature and time of exposure to atmospheric oxygen. All of these factors are at the basis of the efficacy of milk storage conditions. Moreover, our data demonstrate that milk, several weeks after its expiry date, is a rich source of fatty acids that may be recovered as potential substrates for the formulation of economically viable products and eco-friendly diesel-like fuels.
\end{abstract}

\section{Introduction}

Milk is considered a complete food, with true nutraceutical properties. It contains a wide range of bioactive compounds that exert healthy properties to both neonates and humans [1] such as proteins, sugars, mineral salts, vitamins, and lipids. Nutraceutical formulations are often based on milk bioactive peptides, which are usually latent and become active when released after proteolysis of the parent proteins [2]. Nevertheless, lipids represent another important component of milk, being able to influence the physical, organoleptic, and nutritional properties of dairy products and playing an important role in human health promotion and diseases prevention. However, lipid composition of dairy products undergoes far-reaching changes during storage, which can reduce the shelf life and quality of milk and modify the overall flavor [3]. For these reasons, milk is increasingly subjected to quality control and safety assessment [4] through the evaluation of the chemical composition and purity as well as levels of different microorganisms which are responsible for 
the lipolysis and lipid oxidation phenomena. Lipolysis in milk consists in the hydrolysis of triglycerides into free fatty acids (FFA) and partial glycerides. This process can be mediated by the lipoprotein lipases (LPLs) naturally occurring in milk or by the microbial lipases from psychrotrophic bacteria contaminating the raw milk during cold storage $[5,6]$. Since LPLs are relatively unstable to heat, pasteurization inactivates most of the enzyme, so that lipolysis rate is significantly decreased in pasteurized homogenized milk [7]. The release of short- and medium-chain FFA (from $\mathrm{C}_{4}$ to $\mathrm{C}_{10}$ ) and their subsequent conversion to other acids and/or ethyl esters by microbial lipases produce detrimental features such as rancid smell and taste and functionality defects [8].

Milk fatty acid composition is a key factor determining its storage condition. Cow milk, similar to sheep and goat milk, contains almost 3 times less C14:0 (myristic) acid and 2 times more C16:0 (palmitic) acid than buffalo milk [9]. It has been reported that cow milk fat in comparison to goat milk fat contains $54.6 \%$ less C6:0 acid, 69.9\% C8:0, 80.2\% C10:0, and 56.3\% CLA and 75\% more C4:0 acid [9]. Donkey milk contains several times more saturated fatty acids (SFAs) (C8:0, C10:0, and C12:0), twice less of C14:0 and C16:0 fatty acids, and ten times less of (C18:0) stearic acid (1.12\%) than cow. In donkey milk, the amount of C18:1 (oleic) acid is 3 times smaller than in milk of other species. Among common species, donkey milk is one of the richest in polyunsaturated fatty acids (PUFAs), C18:2, and C18:3 (linoleic and linolenic) [9].

Milk fatty acid composition mainly depends on the nutrition of the animals [10, 11]. Actually, many strategies have been adopted in the attempt to adjust the fatty acid profile of milk in order to ameliorate its nutritional quality and to increase its benefits on human health. Dairy cows have been fed on oils and mixture of vegetable fats to increase the content of PUFAs in milk [12, 13]. Nevertheless, any increase in PUFA content had negative effects on milk, making it more susceptible to oxidation [14]. In fact, lipid oxidation in milk is highly influenced by its content of unsaturated fatty acids at a rate that especially depends on the degree of unsaturation (Timmons et al. (2001) [15]). Therefore, dairy products from cows fed on diets rich in PUFAs are prone to oxidation if no precautions against oxidation are taken, such as adding natural antioxidants to the raw milk $[16,17]$. Moreover, numerous nutraceutical formulations for the treatment of oxidative stress conditions [18] and cardiovascular diseases [19] are based on natural phytochemical extracts such as polyphenols $[20,21]$ and carotenoids also recovered from food by-products [22] together with PUFA from dairy wastewater, characterized by high fat content. In large dairy industries, while cleaning the equipment, the residual butter and related fats are washed out and collected in the effluent treatment plant. This by-product is usually disposed as solid waste or incinerated. However, this strategy is not economically advantageous and generates pollutants. One possible solution could be to convert the dairy wastewater into biodiesel and use it as an alternative fuel [23]. Recently, global attention has been focusing on food industry waste products as fat sources for developing safe, alternative fuels that are economically viable and environmentally friendly
[24]. Biodiesel, which is defined as a non-petroleum-based diesel fuel, is a mono-alkyl (methyl, propyl, or ethyl) ester of long chain fatty acids. Biodiesel is regarded as an alternative fuel with similar performance characteristics to petroleum diesel. It is produced by reacting fats and oils (e.g., vegetable oils and animal fats) with alcohol in the presence of a catalyst. The feedstock for biodiesel is largely triglyceride oils which may be edible vegetable oils such as soybean (commonly used for biodiesel production in the United States) and rapeseed (canola) oil (major feedstock for its production in Europe). However, the global emphasis has been focusing on the production of biodiesel from low-cost feedstock, such as waste cooking oil (WCO), which is more economical and environmentally friendly [25]. Similarly, other fat-based waste products may be taken into consideration for the production of alternative fuels such as dairy waste.

In the light of these considerations, the objective of this study was to determine the qualitative and quantitative variation of single fatty acids in cow milk samples before expiration date and within 28 days after expiration date in order to monitor how the profile of the lipid fraction is influenced by different physicochemical parameters.

\section{Materials and Methods}

2.1. Materials. Acetonitrile, clarifying reagent for dairy products, ethylenediaminetetraacetic acid, $N, N$-dimethylformamide, $n$-hexane, 4-nitrophenol, 4-nitrophenyl butyrate, phenolphthalein, phenylmethanesulfonyl fluoride, 2-propanol, sodium sulfate, sodium hydroxide, and Tris-buffered saline (TBS) were purchased from Sigma-Aldrich (St. Louis, MO, USA).

2.2. Sampling and Sample Preparation. Commercial samples of bovine milk (skimmed, semiskimmed, and whole) from Centrale del latte di Salerno (CdLdS) (Salerno, Campania, Italy) were analyzed; samples were preserved at room temperature and the corresponding fatty acids were extracted at different weeks after expiration date. The lipid fraction was obtained from milk by liquid-liquid extraction (LLE). An aliquot of $15 \mathrm{~mL}$ of milk was treated with $50 \mathrm{~mL}$ of a mixture of isopropanol and $n$-hexane $(3: 2 \mathrm{v} / \mathrm{v})$. This solution was stirred vigorously for $10-15 \mathrm{~min}$ and the hexane phase was recovered. The extraction procedure was repeated twice and the combined hexane fractions were dehydrated first with $15 \mathrm{~mL}$ of $0.47 \mathrm{M} \mathrm{Na}_{2} \mathrm{SO}_{4}$ solution and then treated with $\mathrm{Na}_{2} \mathrm{SO}_{4}(3 \mathrm{~g})$ for final dehydration. After solvent removal under vacuum, the lipid extract was dried at $40^{\circ} \mathrm{C}$ to constant weight. An aliquot of $50 \mu \mathrm{g}$ of lipid extract was dissolved in dry toluene $(1 \mathrm{~mL})$ and then treated with $1 \mathrm{M}$ sodium methoxide in dry methanol $(1 \mathrm{~mL})$ to convert fatty acids and complex lipids into their corresponding methyl esters (FAMEs) and analyzed by GC-MS.

2.3. Gas Chromatography-Mass Spectrometry Analysis. Gas chromatography-mass spectrometry analyses (GC-MS) were carried out employing an Agilent 6850 Series II apparatus coupled to an Agilent Mass Selective Detector (MSD) 5273. A fused silica HP-5MS capillary column was used $(30 \mathrm{~m}$ 
$\times 0.25 \mathrm{~mm}$ i.d., $0.33 \mu \mathrm{m}$ film thickness). MS detection was performed using an ionization voltage of $70 \mathrm{eV}$, an electron multiplier energy of $2000 \mathrm{~V}$, and a scan range of 40-550. Injector and detector temperatures were set at 250 and $280^{\circ} \mathrm{C}$, respectively. Column temperature was set at $140^{\circ} \mathrm{C}$ for $10 \mathrm{~min}$, followed by a first ramp of $15^{\circ} \mathrm{C} / \mathrm{min}$ until $200^{\circ} \mathrm{C}$. This temperature was maintained for $1 \mathrm{~min}$; then a second ramp of $10^{\circ} \mathrm{C} / \mathrm{min}$ was used until $230^{\circ} \mathrm{C}$. After $1 \mathrm{~min}$, a third ramp of $0.4^{\circ} \mathrm{C} / \mathrm{min}$ was applied until the temperature of $233^{\circ} \mathrm{C}$. After $3 \mathrm{~min}$, the final ramp of $0.5^{\circ} \mathrm{C} / \mathrm{min}$ was used till reaching the final temperature of $238^{\circ} \mathrm{C}$ and maintained for further 2 minutes. Total analysis time was $41.50 \mathrm{~min}$. Gases flow rates (White Martins) were $30 \mathrm{~mL} / \mathrm{min}$ for hydrogen, $30 \mathrm{~mL} / \mathrm{min}$ for nitrogen, and $250 \mathrm{~mL} / \mathrm{min}$ for synthetic air. Each injection $(1.2 \mu \mathrm{L})$ was performed in duplicate. The peak areas of FAMEs were determined using ChromQuest 4.1 software.

2.4. Acidity and $p H$ Analysis. The $\mathrm{pH}$ value and total acidity were determined in commercial milk samples (skimmed, semiskimmed, and whole milk) at different weeks after their expiration date. The $\mathrm{pH}$ values were measured using a digital $\mathrm{pH}$ meter of a glass electrode (BASIC 20, Crison). Prior to use, the $\mathrm{pH}$ meter was calibrated with standard buffer solution ( $\mathrm{pH} 4$ and 7). Total titratable acidity (TA) was determined according to the AOAC method [26]. TA was determined by measuring the volume $(\mathrm{mL})$ of $0.25 \mathrm{~N}$ sodium hydroxide required to titrate $100 \mathrm{~mL}$ of milk sample, using phenolphthalein as an indicator (five drops). The milk sample was titrated to a faint pink color that persisted after vigorous shaking (end-point). The volume of titrant consumed corresponded to the amount of lactic acid present in the sample. The results were expressed in Soxhlet-Henkel degree $\left({ }^{\circ} \mathrm{SH}\right)$.

2.5. Total Lipase Activity Assay. A spectrophotometric method was developed in order to determine the total activity of the lipase (TLA) in milk samples, thus determining the amount of free fatty acids (FFA) liberated from the triglycerides contained in bovine milk [27]. Through this method it is possible to quantify the level of $p$-nitrophenol ( $A_{\max } 400$ to $420 \mathrm{~nm}$ ) released after the lipase-catalyzed hydrolysis of $p$-nitrophenyl butyrate, used as a substrate. The analysis was performed on different milk samples (skimmed, semiskimmed, and whole milk) at different weeks after their expiration date. The lipase activity was assayed by detecting $p$-nitrophenol on a Genesys 10S UV-Vis Spectrophotometer (Thermo Fisher Scientific Inc., San Jose, California). The analyses were carried out at room temperature and the absorbance was measured at $420 \mathrm{~nm}$. $p$-Nitrophenol was liberated by incubating $500 \mu \mathrm{L}$ of milk sample with $50 \mu \mathrm{L}$ of $0.05 \mathrm{mM} p$-nitrophenol butyrate standard solution and $2 \mathrm{~mL}$ of $0.05 \mathrm{M}$ Tris buffer, $\mathrm{pH} 7.6$, at $37^{\circ} \mathrm{C}$ for exactly $30 \mathrm{~min}$. The reaction was terminated by incubation at $37^{\circ} \mathrm{C}$ for $10 \mathrm{~min}$ with $400 \mu \mathrm{L}$ of a solution composed by $3: 1(\mathrm{v} / \mathrm{v}) 0.06 \mathrm{M}$ EDTA, pH 7.6, in $\mathrm{NaOH} 2 \mathrm{~N}$ and phenylmethanesulfonyl fluoride (PMSF) $0.06 \mathrm{M}$ in dimethylformamide. This solution was diluted with $2 \mathrm{~mL}$ of clarifying reagent solution at $37^{\circ} \mathrm{C}$ for $5 \mathrm{~min}$ to render casein micelles and fat globules soluble and allow direct spectrophotometric measurements without preliminary separation. The final solution was analyzed at $420 \mathrm{~nm}$ against corresponding solvent blank that was prepared in the same assay conditions, except that lipase activity inhibitors were added to the milk sample before adding the substrate solution. Lipase activity was determined by comparing sample $A_{420}$ values with those of a standard curve prepared with $p$-nitrophenol.

2.6. Data Analysis. The experimental results were expressed as mean \pm standard deviation (SD, $n \geq 3$ ). Statistical analysis of data was performed by Student's $t$-test or by two-way ANOVA followed by the Tukey-Kramer multiple comparison post hoc test. The level of significance ( $\alpha$-value) was $95 \%$ $(P<0.05)$. The degree of linear relationship between two variables was measured using the Pearson product moment correlation coefficient $(R)$. Correlation coefficients $(R)$ were calculated using Microsoft Office Excel.

\section{Results and Discussion}

3.1. Lipase Activity in the Milk Samples. Lipases are an important group of enzymes, being associated with fat metabolism. In particular, these enzymes hydrolyse the glycerol esters of fatty acids at the oil/water interface and are responsible for the production of undesirable rancid flavors [28]. The activity of lipase in milk is highly correlated to its acidity, a determining factor for assessing the quality of milk products. There are two main conventions for expressing acidity in dairy products: titratable acidity and $\mathrm{pH}$. Titratable acidity (TA) plays a fundamental role in all phases of milk coagulation. This includes the aggregation rate of para-casein micelles and the reactivity of rennet. TA also influences the rate of syneresis and determines the suitability of milk for cheese making. The $\mathrm{pH}$ of milk affects not only the enzymatic reactions but also its colloidal stability. Table 1 shows the $\mathrm{pH}$ and TA values of 15 commercial milk samples analyzed at several weeks after their expiry date. The results show that $\mathrm{pH}$ values were in the range of 6.71-4.23 in skimmed milk, 6.72-4.28 in semiskimmed milk, and 6.72-4.61 in whole milk. The values of TA were in the range of 6.36-58.15 in skimmed milk, 6.17-52.22 in semiskimmed milk, and 6.17-56.75 in whole milk. This decrease in $\mathrm{pH}$ was attributed to increased lactic acid levels produced by fermenting bacteria. TA also increased for the same reasons.

Both the $\mathrm{pH}$ values and the degree of acidity did not change in a regular manner over time. This could probably be ascribed to the different types of fermentation (both acidic and putrefactive) which can occur in milk, since its initial microbial load is heterogeneous. However, as shown in Table 1, TA was inversely correlated with the lipase activity level $(R=0.9178,0.8545$ and 0.8392 for skimmed, semiskimmed, and whole milk, resp.) that has been demonstrated to be highly sensitive to $\mathrm{pH}$. Most of lipases in milk have $\mathrm{pH}$ optimum values of 8.5-9.0, while other lipases have $\mathrm{pH}$ optimum values ranging from 6.5 to 7.9 . In the milk samples analyzed, lipase activity was significantly low at acidic $\mathrm{pH}$ values. In fact, at $\mathrm{pH}$ values of $6.71,5.85$, $4.91,4.33$, and 4.23 , the amount of $p$-nitrophenol generated in skimmed milk was $70.8 \%, 57.1 \%, 18.3 \%$, and $1.7 \%$, respectively. 
TABLE 1: pH, titratable acidity, and lipase activity of skimmed, semiskimmed, and whole milk samples at four weeks after their expiration date.

\begin{tabular}{lcccccc}
\hline & Milk samples & T0 & Week I & Week II & Week III & Week IV \\
\hline \multirow{2}{*}{ pH value $^{*}$} & Skimmed milk & $6.71 \pm 0.01^{\mathrm{a}}$ & $4.33 \pm 0.01^{\mathrm{d}}$ & $4.23 \pm 0.01^{\mathrm{e}}$ & $4.91 \pm 0.01^{\mathrm{c}}$ & $5.85 \pm 0.02^{\mathrm{b}}$ \\
& Semiskimmed milk & $6.72 \pm 0.02^{\mathrm{a}}$ & $5.51 \pm 0.01^{\mathrm{b}}$ & $4.55 \pm 0.01^{\mathrm{c}}$ & $4.28 \pm 0.01^{\mathrm{e}}$ & $4.41 \pm 0.01^{\mathrm{d}}$ \\
& Whole milk & $6.72 \pm 0.02^{\mathrm{a}}$ & $5.38 \pm 0.05^{\mathrm{b}}$ & $4.61 \pm 0.01^{\mathrm{e}}$ & $5.22 \pm 0.02^{\mathrm{c}}$ & $4.73 \pm 0.01^{\mathrm{d}}$ \\
\hline \multirow{2}{*}{ Titratable acidity, $^{*, \#}$} & Skimmed milk & $6.36 \pm 0.03^{\mathrm{e}}$ & $35.57 \pm 0.49^{\mathrm{b}}$ & $58.15 \pm 0.46^{\mathrm{a}}$ & $28.93 \pm 0.40^{\mathrm{c}}$ & $16.70 \pm 0.01^{\mathrm{d}}$ \\
& Semiskimmed milk & $6.17 \pm 0.03^{\mathrm{e}}$ & $23.41 \pm 0.40^{\mathrm{d}}$ & $52.22 \pm 0.08^{\mathrm{a}}$ & $37.00 \pm 0.50^{\mathrm{c}}$ & $41.66 \pm 0.31^{\mathrm{b}}$ \\
& Whole milk & $6.17 \pm 0.10^{\mathrm{e}}$ & $30.20 \pm 0.05^{\mathrm{c}}$ & $56.75 \pm 0.03^{\mathrm{a}}$ & $20.56 \pm 0.47^{\mathrm{d}}$ & $45.45 \pm 0.19^{\mathrm{b}}$ \\
\hline \multirow{2}{*}{ Lipase activity $^{*, \$}$} & Skimmed milk & $0.024 \pm 0.007^{\mathrm{a}}$ & $0.0044 \pm 0.0030^{\mathrm{d}}$ & $0.0004 \pm 0.0005^{\mathrm{e}}$ & $0.0137 \pm 0.0120^{\mathrm{c}}$ & $0.017 \pm 0.011^{\mathrm{b}}$ \\
& Semiskimmed milk & $0.011 \pm 0.003^{\mathrm{a}}$ & $0.0037 \pm 0.0021^{\mathrm{b}}$ & $0.0008 \pm 0.0005^{\mathrm{c}}$ & $0.0011 \pm 0.0004^{\mathrm{c}}$ & $0.001 \pm 0.005^{\mathrm{c}}$ \\
& Whole milk & $0.006 \pm 0.001^{\mathrm{a}}$ & $0.0012 \pm 0.0011^{\mathrm{c}}$ & $0.0001 \pm 0.0005^{\mathrm{d}}$ & $0.0054 \pm 0.0010^{\mathrm{b}}$ & $0.001 \pm 0.001^{\mathrm{c}}$ \\
\hline
\end{tabular}

${ }^{*}$ Milk samples were analyzed in triplicate. Values are expressed \pm SD. ${ }^{*}$ Data were expressed in Soxhlet-Henkel degree. ${ }^{\S}$ Data were expressed as $\mu$ mol of $p$ nitrophenol/mL reaction mixture. Means in the same row followed by different inline letters ( $\mathrm{a}, \mathrm{b}, \mathrm{c}, \mathrm{d}$, and e) are statistically different according to Tukey's HSD test $(P<0.05)$.

Conversely, the percentage of lipase activity in whole milk decreased by $10.0 \%, 80.0 \%, 83.3 \%$, and $98.3 \%$, corresponding to increasing TA values. In contrast to other enzymes, the rate at which a lipase-catalyzed reaction proceeds is not governed by the substrate concentration at the interface between the lipid substrate and the aqueous phase of an emulsion, but it is dependent on the amount of free fatty acids, which are released by disruption of the milk fat globule, exposing the lipid substrate to the lipase [29].

3.2. Fatty Acid Profile of Milk before Expiration Date. The fatty acid composition of skimmed, semiskimmed, and whole milk samples before their expiration date is reported in Table 2. The saturated fatty acids accounted for $64.3,47.3$, and $42.9 \%$ of total fatty acids in whole, semiskimmed, and skimmed milk, respectively. The most abundant among saturated fatty acids was palmitic acid (16:0) (43\%), followed by myristic acid $(14: 0)(16 \%)$, stearic acid (18:0) (17.5\%), and short-chain fatty acids (C4:0-C10:0) (15\%) in all milk samples. Monounsaturated fatty acids represented $31.0,46.8$, and $51.7 \%$ of total fatty acids in whole, semiskimmed, and skimmed milk, respectively. Oleic acid (18:1) was the main monounsaturated fatty acid, accounting approximately for $77.5 \%$. Polyunsaturated fatty acids accounted for 4.7, 5.9, and 5.4 of total fatty acids in whole, semiskimmed, and skimmed milk, respectively. Among them, the main constituents were dihomo-gammalinolenic acid (20:3n-6) (28.4\%) and conjugated linoleic acid (CLAc9t11) (23.8\%). The ratio between $n-6$ and $n-3$ fatty acids in whole and semiskimmed milk was 2,1:1, while in skimmed milk it was $2,3: 1$.

3.3. Fatty Acid Profile after Expiration Date. Analysis of milk samples carried out at different weeks after their expiration date showed a gradual decrease in their amount of unsaturated fatty acids, while unchanged quantities of saturated fatty acids were detected. After first, second, third, and fourth weeks, the percentage of degradation of both monounsaturated and polyunsaturated fatty acids of whole and semiskimmed milk was $25 \%, 44 \%, 58 \%$, and $69 \%$, respectively (Tables 3 and 4 ). The degradation process of some unsaturated fatty acids in skimmed milk was not constant as that observed for the other samples (Table 5). The amount of trans-9 cis-12 octadienoic acid after one week was unchanged, while alpha-linolenic acid remained constant up to two weeks. Linolelaidic, heptadec-10-enoic and cis-vaccenic acids decreased by $20 \%$ at first week, $40 \%$ at second week, and $60 \%$ at third and fourth weeks.

On the basis of the above-mentioned data, it is evident that the amount of unsaturated fatty acids decreased over time, apparently independent of $\mathrm{pH}$, titratable acidity, and type of milk. On the contrary, crucial parameters for the fatty acid degradation were storage temperature and time of exposure to atmospheric oxygen, at the base of the lipid oxidation process in milk samples.

Knowing how to dispose of waste milk properly is an essential part of dairy industry management. Serious problems can develop when waste milk is handled incorrectly. These include damage to the environment and, potentially, a failed wastewater treatment system. In fact, improper handling of waste milk is the main reason why wastewater systems fail. Due to its high organic compound and phosphorus content, milk can promote the growth of algae and aquatic plants which increase the oxygen demand and the likelihood of fish death. Several milk disposal methods have been recently proposed in order to face the environmental pollution question, mainly: feeding to livestock, use as a soil fertilizer, and manufacturing soaps.

Actually, the employment of waste milk as a source for alternative biofuels has recently gained general interest. Lateef et al. [30] have shown that inclusion of waste milk as a cosubstrate during biohydrogen production from cow manure could improve hydrogen production that is readily turned into methane, the final product of anaerobic digestion process. Nevertheless, biodiesel which is derived 
TABLE 2: Fatty acids composition (MG/G total fatty acids) of the commercial samples of bovine milk (skimmed, semiskimmed, and whole) from Centrale del Latte di Salerno before their expiration date.

\begin{tabular}{|c|c|c|c|}
\hline Fatty acids & Whole milk & Semiskimmed milk & Skimmed milk \\
\hline Saturated ${ }^{*}$ & $589.04 \pm 0.58^{a}$ & $111.31 \pm 0.30^{b}$ & $2.99 \pm 0.24^{c}$ \\
\hline Butyric (C4:0) & $34.25 \pm 0.74^{\mathrm{a}}$ & $6.39 \pm 0.21^{\mathrm{b}}$ & $0.17 \pm 0.05^{\mathrm{c}}$ \\
\hline Caproic (C6:0) & $21.29 \pm 0.39^{\mathrm{a}}$ & $3.97 \pm 0.27^{\mathrm{b}}$ & $0.11 \pm 0.06^{\mathrm{c}}$ \\
\hline Caprylic (C8:0) & $11.77 \pm 0.27^{\mathrm{a}}$ & $2.19 \pm 0.32^{\mathrm{b}}$ & $0.06 \pm 0.07^{\mathrm{c}}$ \\
\hline Capric (C10:0) & $22.46 \pm 0.37^{\mathrm{a}}$ & $4.19 \pm 0.43^{b}$ & $0.11 \pm 0.08^{\mathrm{c}}$ \\
\hline Lauric (C12:0) & $25.52 \pm 0.42^{\mathrm{a}}$ & $4.76 \pm 0.54^{\mathrm{b}}$ & $0.13 \pm 0.09^{c}$ \\
\hline Tridecanoic acid (C13:0) & $0.84 \pm 0.57^{\mathrm{a}}$ & $0.16 \pm 0.05^{\mathrm{b}}$ & $0.004 \pm 0.001^{\mathrm{c}}$ \\
\hline Myristic (C14:0) & $93.78 \pm 0.66^{\mathrm{a}}$ & $17.51 \pm 0.76^{\mathrm{b}}$ & $0.48 \pm 0.40^{c}$ \\
\hline Pentadecanoic (C15:0) & $13.80 \pm 0.71^{\mathrm{a}}$ & $2.58 \pm 0.88^{\mathrm{b}}$ & $0.07 \pm 0.01^{\mathrm{c}}$ \\
\hline Palmitic (C16:0) & $251.70 \pm 0.85^{\mathrm{a}}$ & $46.99 \pm 0.92^{\mathrm{b}}$ & $1.28 \pm 0.47^{\mathrm{c}}$ \\
\hline Margaric (C17:0) & $8.07 \pm 0.74^{\mathrm{a}}$ & $1.51 \pm 0.84^{\mathrm{b}}$ & $0.04 \pm 0.03^{c}$ \\
\hline Stearic $(\mathrm{C} 18: 0)$ & $103.90 \pm 0.68^{\mathrm{a}}$ & $19.40 \pm 0.74^{\mathrm{b}}$ & $0.53 \pm 0.21^{\mathrm{c}}$ \\
\hline Arachidic (C20:0) & $1.66 \pm 0.51^{\mathrm{a}}$ & $1.66 \pm 0.65^{\mathrm{a}}$ & $0.008 \pm 0.003^{b}$ \\
\hline Monounsaturated ${ }^{*}$ & $283.68 \pm 0.44^{a}$ & $110.13 \pm 0.56^{b}$ & $3.61 \pm 0.43^{c}$ \\
\hline Myristoleic (C14:1) & $8.99 \pm 0.32^{\mathrm{a}}$ & $3.49 \pm 0.47^{\mathrm{b}}$ & $0.09 \pm 0.04^{\mathrm{c}}$ \\
\hline Palmitoleic (C16:1) & $12.13 \pm 0.26^{\mathrm{a}}$ & $4.70 \pm 0.50^{\mathrm{b}}$ & $0.12 \pm 0.05^{\mathrm{c}}$ \\
\hline Heptadec-10-enoic acid (C17:1) & $5.60 \pm 0.18^{\mathrm{a}}$ & $2.17 \pm 0.33^{\mathrm{b}}$ & $0.05 \pm 0.06^{\mathrm{c}}$ \\
\hline Elaidic $(\mathrm{C} 18: \ln -9 \mathrm{t})$ & $25.51 \pm 0.25^{\mathrm{a}}$ & $9.89 \pm 0.27^{\mathrm{b}}$ & $0.27 \pm 0.04^{\mathrm{c}}$ \\
\hline Oleic (C18:1n-9c) & $216.70 \pm 0.34^{\mathrm{a}}$ & $84.05 \pm 0.11^{\mathrm{b}}$ & $2.92 \pm 0.87^{\mathrm{c}}$ \\
\hline Vaccenic acid $(\mathrm{C} 18: 1 n-7 \mathrm{t})$ & $9.47 \pm 0.47^{\mathrm{a}}$ & $3.78 \pm 0.57^{\mathrm{b}}$ & $0.10 \pm 0.04^{\mathrm{c}}$ \\
\hline cis-Vaccenic acid (C18:1n-7c) & $5.28 \pm 0.50^{\mathrm{a}}$ & $2.05 \pm 0.63^{\mathrm{b}}$ & $0.056 \pm 0.004^{\mathrm{c}}$ \\
\hline Polyunsaturated ${ }^{*}$ & $42.88 \pm 0.63^{a}$ & $13.97 \pm 0.70^{b}$ & $0.38 \pm 0.35^{c}$ \\
\hline Linolelaidic (C18:2n-6t) & $5.56 \pm 0.72^{\mathrm{a}}$ & $1.81 \pm 0.81^{\mathrm{b}}$ & $0.05 \pm 0.04^{\mathrm{c}}$ \\
\hline trans -9, cis-12 octadienoic acid $(\mathrm{C} 18: 2 \mathrm{t} 9 \mathrm{c} 12)$ & $2.54 \pm 0.92^{\mathrm{a}}$ & $0.83 \pm 0.09^{b}$ & $0.02 \pm 0.01^{\mathrm{c}}$ \\
\hline Gamma-linoleic $(\mathrm{C} 18: 2 n-6)$ & $8.01 \pm 0.84^{\mathrm{a}}$ & $2.61 \pm 0.79^{b}$ & $0.07 \pm 0.03^{\mathrm{c}}$ \\
\hline Alpha-linolenic (C18:3n-3) & $3.82 \pm 0.79^{\mathrm{a}}$ & $1.24 \pm 0.68^{\mathrm{b}}$ & $0.03 \pm 0.07^{\mathrm{c}}$ \\
\hline Dihomo-gamma-linolenic acid (C20:3n-6) & $11.99 \pm 0.60^{\mathrm{a}}$ & $3.91 \pm 0.57^{\mathrm{b}}$ & $0.11 \pm 0.05^{\mathrm{c}}$ \\
\hline Conjugated linoleic acid (CLAc9t11) & $10.18 \pm 0.53^{\mathrm{a}}$ & $3.32 \pm 0.46^{\mathrm{b}}$ & $0.09 \pm 0.04^{c}$ \\
\hline Conjugated linoleic acid (CLAt10c12) & $0.78 \pm 0.04^{\mathrm{a}}$ & $0.25 \pm 0.03^{\mathrm{b}}$ & $0.007 \pm 0.001^{\mathrm{c}}$ \\
\hline
\end{tabular}

${ }^{*}$ Milk samples were analyzed in triplicate. Values are expressed \pm SD. Means in the same row followed by different inline letters (a, b, and c) are statistically different according to Tukey's HSD test $(P<0.05)$.

from triglycerides by transesterification has been attracting considerable attention as a renewable, biodegradable, ecofriendly, and nontoxic fuel [24]. Biodiesel is currently more expensive than pure diesel, since costs of biodiesel production are highly dependent on the costs of feedstock [31, 32]. At present, partially or fully refined and edible-grade vegetable oils such as soybean, rapeseed, sunflower, and palm oil are the predominant feedstock for biodiesel production, which obviously results in the high price of biodiesel. Therefore, waste edible oil such as waste cooking oil seems to be a good substitute in order to reduce cost [33]. Our data (Tables 3-5) demonstrated that expired milk is still rich in those fatty acids that are the main constituents of the waste cooking oils used for the biodiesel production, such as palmitic, myristic, and oleic acids [34]. What is more, a significant amount of these glycerides in the expired milk already occurs in a hydrolysed form so that minor quantities of catalysts than employed for waste cooking oils for the esterification and transesterification reactions would be necessary, partially solving an economical and environmental question.

\section{Conclusion}

In conclusion, the present study showed that lipolysis in milk is a process independent of time but dependent on the values of $\mathrm{pH}$ and TA, while crucial parameters for the lipid oxidation are temperature and time of exposure to atmospheric oxygen. All of these factors are at the base of the efficacy of milk storage conditions. Moreover, our data demonstrated that milk several weeks after its expiration date is a rich source of fatty acids that may be recovered as a potential substrate for the formulation of alternative diesel-like fuels. 
TABLE 3: Fatty acid profile (MG/G total fatty acids) of whole milk samples at different weeks after their expiration date.

\begin{tabular}{|c|c|c|c|c|c|}
\hline Whole milk & T0 & Week I & Week II & Week III & Week IV \\
\hline \multicolumn{6}{|l|}{ Monounsaturated ${ }^{*}$} \\
\hline Myristoleic (C14:1) & $8.99 \pm 0.32^{\mathrm{a}}$ & $6.74 \pm 0.49^{\mathrm{b}}$ & $5.06 \pm 0.23^{c}$ & $3.79 \pm 0.36^{\mathrm{d}}$ & $2.84 \pm 0.32^{\mathrm{e}}$ \\
\hline Palmitoleic (C16:1) & $12.13 \pm 0.41^{\mathrm{a}}$ & $9.10 \pm 0.55^{\mathrm{b}}$ & $6.82 \pm 0.34^{\mathrm{c}}$ & $5.12 \pm 0.48^{\mathrm{d}}$ & $3.84 \pm 0.32^{\mathrm{e}}$ \\
\hline Heptadec-10-enoic acid (C17:1) & $5.60 \pm 0.58^{\mathrm{a}}$ & $4.20 \pm 0.32^{\mathrm{b}}$ & $3.15 \pm 0.45^{\mathrm{c}}$ & $2.36 \pm 0.88^{\mathrm{c}, \mathrm{d}}$ & $1.77 \pm 0.17^{\mathrm{d}}$ \\
\hline Elaidic (C18:1n-9t) & $25.51 \pm 0.60^{\mathrm{a}}$ & $19.13 \pm 0.32^{\mathrm{b}}$ & $14.35 \pm 0.56^{\mathrm{c}}$ & $10.76 \pm 0.93^{\mathrm{d}}$ & $8.07 \pm 0.27^{\mathrm{e}}$ \\
\hline Oleic $(\mathrm{C} 18: \ln -9 \mathrm{c})$ & $216.70 \pm 1.18^{\mathrm{a}}$ & $162.53 \pm 0.62^{\mathrm{b}}$ & $121.89 \pm 1.05^{\mathrm{c}}$ & $91.42 \pm 1.01^{\mathrm{d}}$ & $68.57 \pm 0.93^{\mathrm{e}}$ \\
\hline Vaccenic acid $(\mathrm{C} 18: 1 n-7 \mathrm{t})$ & $9.47 \pm 0.72^{\mathrm{a}}$ & $7.10 \pm 0.73^{\mathrm{b}}$ & $5.33 \pm 0.66^{c}$ & $4.00 \pm 0.13^{\mathrm{d}}$ & $3.00 \pm 0.22^{\mathrm{e}}$ \\
\hline cis-Vaccenic acid (C18:1n-7c) & $5.28 \pm 0.86^{\mathrm{a}}$ & $3.96 \pm 0.48^{\mathrm{a}, \mathrm{b}}$ & $2.97 \pm 0.74^{\mathrm{b}, \mathrm{c}}$ & $2.23 \pm 0.14^{\mathrm{c,d}}$ & $1.67 \pm 0.24^{\mathrm{d}}$ \\
\hline \multicolumn{6}{|l|}{ Polyunsaturated ${ }^{*}$} \\
\hline Linolelaidic (C18:2n-6t) & $5.56 \pm 0.76^{\mathrm{a}}$ & $4.17 \pm 0.74^{\mathrm{a}, \mathrm{b}}$ & $3.13 \pm 0.83^{b, c}$ & $2.35 \pm 0.28^{\mathrm{c}, \mathrm{d}}$ & $1.76 \pm 0.33^{\mathrm{d}}$ \\
\hline trans- 9 , cis-12 octadienoic acid (C18:2t9c12) & $2.54 \pm 0.64^{\mathrm{a}}$ & $1.91 \pm 0.66^{\mathrm{a}, \mathrm{b}}$ & $1.43 \pm 0.37^{\mathrm{b}, \mathrm{c}}$ & $1.07 \pm 0.37^{\mathrm{c}, \mathrm{d}}$ & $0.80 \pm 0.36^{\mathrm{d}}$ \\
\hline Gamma-linoleic (C18:2n-6) & $8.01 \pm 0.53^{\mathrm{a}}$ & $6.01 \pm 0.59^{\mathrm{b}}$ & $4.51 \pm 0.58^{\mathrm{c}}$ & $3.38 \pm 0.46^{\mathrm{d}}$ & $2.53 \pm 0.21^{\mathrm{e}}$ \\
\hline Alpha-linolenic (C18:3n-3) & $3.82 \pm 0.41^{\mathrm{a}}$ & $2.87 \pm 0.40^{\mathrm{a}, \mathrm{b}}$ & $2.15 \pm 0.49^{b, c}$ & $1.61 \pm 0.45^{\mathrm{c,d}}$ & $1.21 \pm 0.27^{\mathrm{d}}$ \\
\hline Dihomo-gamma-linolenic acid (C20:3n-6) & $11.99 \pm 0.37^{\mathrm{a}}$ & $8.99 \pm 0.33^{\mathrm{b}}$ & $6.74 \pm 0.31^{c}$ & $5.06 \pm 0.55^{\mathrm{d}}$ & $3.79 \pm 0.46^{\mathrm{e}}$ \\
\hline Conjugated linoleic acid (CLAc9t11) & $10.18 \pm 0.22^{\mathrm{a}}$ & $7.64 \pm 0.28^{\mathrm{b}}$ & $5.73 \pm 0.22^{\mathrm{c}}$ & $4.29 \pm 0.68^{\mathrm{d}}$ & $3.22 \pm 0.68^{\mathrm{d}}$ \\
\hline Conjugated linoleic acid (CLAt10c12) & $0.78 \pm 0.34^{\mathrm{a}}$ & $0.59 \pm 0.16^{\mathrm{a}, \mathrm{b}}$ & $0.44 \pm 0.32^{\mathrm{b}, \mathrm{c}}$ & $0.33 \pm 0.23^{\mathrm{b}, \mathrm{c}}$ & $0.25 \pm 0.22^{\mathrm{c}}$ \\
\hline
\end{tabular}

${ }^{*}$ Milk samples were analyzed in triplicate. Values are expressed \pm SD. Means in the same row followed by different inline letters (a, b, c, d, and e) are statistically different according to Tukey's HSD test $(P<0.05)$.

TABLE 4: Fatty acid profile (MG/G total fatty acids) of semiskimmed milk samples at different weeks after their expiration date.

\begin{tabular}{|c|c|c|c|c|c|}
\hline Semiskimmed milk & T0 & Week I & Week II & Week III & Week IV \\
\hline \multicolumn{6}{|l|}{ Monounsaturated ${ }^{*}$} \\
\hline Myristoleic (C14:1) & $3.49 \pm 0.23^{\mathrm{a}}$ & $2.62 \pm 0.32^{\mathrm{b}}$ & $1.96 \pm 0.21^{\mathrm{c}}$ & $1.47 \pm 0.37^{\mathrm{c}, \mathrm{d}}$ & $1.10 \pm 0.63^{\mathrm{d}}$ \\
\hline Palmitoleic (C16:1) & $4.70 \pm 0.34^{\mathrm{a}}$ & $3.53 \pm 0.47^{b}$ & $2.64 \pm 0.32^{c}$ & $1.98 \pm 0.47^{\mathrm{c}, \mathrm{d}}$ & $1.49 \pm 0.74^{\mathrm{d}}$ \\
\hline Heptadec-10-enoic acid (C17:1) & $2.17 \pm 0.45^{\mathrm{a}}$ & $1.63 \pm 0.14^{\mathrm{b}}$ & $1.22 \pm 0.17^{\mathrm{c}}$ & $0.92 \pm 0.26^{\mathrm{c}, \mathrm{d}}$ & $0.69 \pm 0.53^{\mathrm{d}}$ \\
\hline Elaidic $(\mathrm{C} 18: 1 n-9 \mathrm{t})$ & $9.89 \pm 0.56^{\mathrm{a}}$ & $7.42 \pm 0.25^{\mathrm{b}}$ & $5.56 \pm 0.56^{\mathrm{c}}$ & $4.17 \pm 0.75^{\mathrm{d}}$ & $3.13 \pm 0.94^{\mathrm{d}}$ \\
\hline Oleic $(\mathrm{C} 18: \ln -9 \mathrm{c})$ & $84.05 \pm 1.05^{\mathrm{a}}$ & $63.04 \pm 0.37^{\mathrm{b}}$ & $47.28 \pm 0.32^{c}$ & $35.46 \pm 0.64^{\mathrm{d}}$ & $26.59 \pm 0.85^{\mathrm{e}}$ \\
\hline Vaccenic acid (C18:1n-7t) & $3.78 \pm 0.66^{\mathrm{a}}$ & $2.84 \pm 0.44^{\mathrm{b}}$ & $2.13 \pm 0.33^{\mathrm{c}}$ & $1.59 \pm 0.53^{\mathrm{c}, \mathrm{d}}$ & $1.20 \pm 0.77^{\mathrm{c}, \mathrm{d}}$ \\
\hline cis-Vaccenic acid (C18:1n-7c) & $2.05 \pm 0.74^{\mathrm{a}}$ & $1.54 \pm 0.35^{\mathrm{a}}$ & $1.15 \pm 0.63^{\mathrm{a}, \mathrm{b}}$ & $0.86 \pm 0.46^{\mathrm{a}, \mathrm{b}}$ & $0.65 \pm 0.63^{\mathrm{b}}$ \\
\hline \multicolumn{6}{|l|}{ Polyunsaturated ${ }^{*}$} \\
\hline Linolelaidic $(\mathrm{C} 18: 2 n-6 \mathrm{t})$ & $1.81 \pm 0.83^{\mathrm{a}}$ & $1.36 \pm 0.46^{\mathrm{a}, \mathrm{b}}$ & $1.02 \pm 0.44^{\mathrm{a}, \mathrm{b}}$ & $0.76 \pm 0.32^{\mathrm{a}, \mathrm{b}}$ & $0.57 \pm 0.50^{\mathrm{a}}$ \\
\hline trans- 9, cis-12 octadienoic acid (C18:2t9c12) & $0.83 \pm 0.17^{\mathrm{a}}$ & $0.62 \pm 0.05^{\mathrm{a}}$ & $0.47 \pm 0.57^{\mathrm{a}, \mathrm{b}}$ & $0.35 \pm 0.29^{\mathrm{a}, \mathrm{b}}$ & $0.26 \pm 0.17^{\mathrm{b}}$ \\
\hline Gamma-linoleic (C18:2n-6) & $2.61 \pm 0.28^{\mathrm{a}}$ & $1.96 \pm 0.14^{\mathrm{b}}$ & $1.47 \pm 0.63^{\mathrm{c}}$ & $1.10 \pm 0.16^{\mathrm{c}, \mathrm{d}}$ & $0.83 \pm 0.46^{\mathrm{d}}$ \\
\hline Alpha-linolenic (C18:3n-3) & $1.24 \pm 0.49^{\mathrm{a}}$ & $0.93 \pm 0.17^{\mathrm{a}}$ & $0.70 \pm 0.71^{\mathrm{a}, \mathrm{b}}$ & $0.52 \pm 0.24^{\mathrm{b}}$ & $0.39 \pm 0.32^{\mathrm{b}}$ \\
\hline Dihomo-gamma-linolenic acid (C20:3n-6) & $3.91 \pm 0.31^{\mathrm{a}}$ & $2.93 \pm 0.22^{\mathrm{b}}$ & $2.20 \pm 0.83^{\mathrm{b}, \mathrm{c}}$ & $1.65 \pm 0.37^{\mathrm{cd} d}$ & $1.24 \pm 0.30^{\mathrm{d}}$ \\
\hline Conjugated linoleic acid (CLAc9t11) & $3.32 \pm 0.12^{\mathrm{a}}$ & $2.49 \pm 0.25^{\mathrm{b}}$ & $1.87 \pm 0.21^{\mathrm{c}}$ & $1.40 \pm 0.43^{\mathrm{c}, \mathrm{d}}$ & $1.05 \pm 0.18^{\mathrm{d}}$ \\
\hline Conjugated linoleic acid (CLAt10c12) & $0.25 \pm 0.02^{\mathrm{a}}$ & $0.19 \pm 0.04^{\mathrm{a}, \mathrm{b}}$ & $0.14 \pm 0.14^{\mathrm{a}, \mathrm{b}}$ & $0.11 \pm 0.08^{\mathrm{b}, \mathrm{c}}$ & $0.08 \pm 0.03^{c}$ \\
\hline
\end{tabular}

${ }^{*}$ Milk samples were analyzed in triplicate. Values are expressed \pm SD. Means in the same row followed by different inline letters (a, b, $c, d$, and e) are statistically different according to Tukey's HSD test $(P<0.05)$.

\section{Additional Points}

Practical Applications. The present work can contribute to clarifying the factors that are at the base of the efficacy of milk storage conditions. Data regarding the milk fatty acid profile after its expiration date may encourage the recovery and use of this waste product as a potential substrate for the formulation of alternative diesel-like fuels.

\section{Conflicts of Interest}

The authors declare that there are no conflicts of interest. 
TABLE 5: Fatty acid profile (MG/G total fatty acids) of skimmed milk samples at different weeks after their expiration date.

\begin{tabular}{lccccc}
\hline Skimmed milk & T0 & Week I & Week II & Week III & Week IV \\
\hline Monounsaturated & & & & \\
Myristoleic & & & & & \\
Palmitoleic & $0.09 \pm 0.02^{\mathrm{a}}$ & $0.07 \pm 0.04^{\mathrm{a}}$ & $0.05 \pm 0.03^{\mathrm{a}}$ & $0.04 \pm 0.04^{\mathrm{a}}$ & $0.03 \pm 0.07^{\mathrm{a}}$ \\
Heptadec-10-enoic acid & $0.12 \pm 0.03^{\mathrm{a}}$ & $0.09 \pm 0.05^{\mathrm{a}}$ & $0.07 \pm 0.07^{\mathrm{a}}$ & $0.05 \pm 0.05^{\mathrm{a}}$ & $0.04 \pm 0.06^{\mathrm{a}}$ \\
Elaidic & $0.05 \pm 0.05^{\mathrm{a}}$ & $0.04 \pm 0.02^{\mathrm{a}}$ & $0.03 \pm 0.03^{\mathrm{a}}$ & $0.02 \pm 0.01^{\mathrm{a}}$ & $0.02 \pm 0.04^{\mathrm{a}}$ \\
Oleic & $0.27 \pm 0.06^{\mathrm{a}}$ & $0.20 \pm 0.06^{\mathrm{a}, \mathrm{b}}$ & $0.15 \pm 0.07^{\mathrm{b}, \mathrm{c}}$ & $0.11 \pm 0.01^{\mathrm{c}, \mathrm{d}}$ & $0.09 \pm 0.07^{\mathrm{d}}$ \\
Vaccenic acid & $2.92 \pm 0.07^{\mathrm{a}}$ & $2.19 \pm 0.07^{\mathrm{b}}$ & $1.64 \pm 0.14^{\mathrm{c}}$ & $1.23 \pm 0.22^{\mathrm{d}}$ & $0.92 \pm 0.04^{\mathrm{e}}$ \\
cis-Vaccenic acid $_{\text {Polyunsaturated }}^{*}$ & $0.10 \pm 0.08^{\mathrm{a}}$ & $0.08 \pm 0.02^{\mathrm{a}}$ & $0.06 \pm 0.01^{\mathrm{a}}$ & $0.04 \pm 0.06^{\mathrm{a}}$ & $0.03 \pm 0.05^{\mathrm{a}}$ \\
Linolelaidic & $0.06 \pm 0.04^{\mathrm{a}}$ & $0.04 \pm 0.03^{\mathrm{a}}$ & $0.03 \pm 0.02^{\mathrm{a}}$ & $0.02 \pm 0.07^{\mathrm{a}}$ & $0.02 \pm 0.03^{\mathrm{a}}$ \\
trans-9, cis-12 octadienoic acid & $0.02 \pm 0.05^{\mathrm{a}}$ & $0.02 \pm 0.02^{\mathrm{a}}$ & $0.01 \pm 0.01^{\mathrm{a}}$ & $0.01 \pm 0.01^{\mathrm{a}}$ & $0.01 \pm 0.01^{\mathrm{a}}$ \\
Gamma-linoleic & $0.07 \pm 0.04^{\mathrm{a}}$ & $0.05 \pm 0.01^{\mathrm{a}}$ & $0.04 \pm 0.02^{\mathrm{a}}$ & $0.03 \pm 0.01^{\mathrm{a}}$ & $0.02 \pm 0.08^{\mathrm{a}}$ \\
Alpha-linolenic & $0.03 \pm 0.03^{\mathrm{a}}$ & $0.02 \pm 0.02^{\mathrm{a}}$ & $0.02 \pm 0.02^{\mathrm{a}}$ & $0.01 \pm 0.01^{\mathrm{a}}$ & $0.01 \pm 0.07^{\mathrm{a}}$ \\
Dihomo-gamma-linolenic acid & $0.11 \pm 0.02^{\mathrm{a}}$ & $0.08 \pm 0.02^{\mathrm{a}, \mathrm{b}}$ & $0.06 \pm 0.03^{\mathrm{b}, \mathrm{c}}$ & $0.05 \pm 0.08^{\mathrm{b}, \mathrm{c}}$ & $0.03 \pm 0.03^{\mathrm{c}}$ \\
Conjugated linoleic acid $_{\text {Conjugated linoleic acid }}$ & $0.09 \pm 0.02^{\mathrm{a}}$ & $0.07 \pm 0.04^{\mathrm{a}, \mathrm{b}}$ & $0.05 \pm 0.01^{\mathrm{b}}$ & $0.04 \pm 0.07^{\mathrm{b}}$ & $0.03 \pm 0.01^{\mathrm{b}}$ \\
\hline
\end{tabular}

${ }^{*}$ Milk samples were analyzed in triplicate. Values are expressed \pm SD. Means in the same row followed by different inline letters (a, b, c, d, and e) are statistically different according to Tukey's HSD test $(P<0.05)$.

\section{References}

[1] E. A. Warner, A. D. Kanekanian, and A. T. Andrews, "Bioactivity of milk proteins: 1 . Anticariogenicity of whey proteins," International Journal of Dairy Technology, vol. 54, no. 4, pp. 151-153, 2001.

[2] G. C. Tenore, A. Ritieni, P. Campiglia et al., "Antioxidant peptides from "Mozzarella di Bufala Campana DOP" after simulated gastrointestinal digestion: In vitro intestinal protection, bioavailability, and anti-haemolytic capacity;" Journal of Functional Foods, vol. 15, pp. 365-375, 2015.

[3] Y. Ma, C. Ryan, D. M. Barbano, D. M. Galton, M. A. Rudan, and K. J. Boor, "Effects of somatic cell count on quality and shelf-life of pasteurized fluid milk," Journal of Dairy Science, vol. 83, no. 2, pp. 264-274, 2000.

[4] L. Grumetto, O. Gennari, D. Montesano et al., "Determination of five bisphenols in commercial milk samples by liquid chromatography coupled to fluorescence detection," Journal of Food Protection, vol. 76, no. 9, pp. 1590-1596, 2013.

[5] S.-Q. Liu, K. Baker, M. Bennett, R. Holland, G. Norris, and V. L. Crow, "Characterisation of esterases of Streptococcus thermophilus ST1 and Lactococcus lactis subsp. cremoris B1079 as alcohol acyltransferases," International Dairy Journal, vol. 14, no. 10, pp. 865-870, 2004.

[6] S.-Q. Liu, R. Holland, and V. L. Crow, "Esters and their biosynthesis in fermented dairy products: A review," International Dairy Journal, vol. 14, no. 11, pp. 923-945, 2004.

[7] H. C. Deeth, "Lipoprotein lipase and lipolysis in milk," International Dairy Journal, vol. 16, no. 6, pp. 555-562, 2006.

[8] M. El-Hofi, E.-S. El-Tanboly, and N. S. Abd-Rabou, "Industrial application of lipases in cheese making: a review," Internet Journal of Food Safety, vol. 13, pp. 293-302, 2011.

[9] J. Barłowska, M. Szwajkowska, Z. Litwińczuk, and J. Król, "Nutritional value and technological suitability of milk from various animal species used for dairy production," Comprehensive Reviews in Food Science and Food Safety, vol. 10, no. 6, pp. 291-302, 2011.

[10] M.-C. Michalski, V. Briard, and P. Juaneda, "CLA profile in native fat globules of different sizes selected from raw milk," International Dairy Journal, vol. 15, no. 11, pp. 1089-1094, 2005.

[11] M. Renna, P. Cornale, C. Lussiana, V. Malfatto, A. Mimosi, and L. M. Battaglini, "Fatty acid profile of milk from goats fed diets with different levels of conserved and fresh forages," International Journal of Dairy Technology, vol. 65, no. 2, pp. 201207, 2012.

[12] J. A. Bell, J. M. Griinari, and J. J. Kennelly, "Effect of safflower oil, flaxseed oil, monensin, and vitamin E on concentration of conjugated linoleic acid in bovine milk fat," Journal of Dairy Science, vol. 89, no. 2, pp. 733-748, 2006.

[13] D. P. Bu, J. Q. Wang, T. R. Dhiman, and S. J. Liu, "Effectiveness of oils rich in linoleic and linolenic acids to enhance conjugated linoleic acid in milk from dairy cows," Journal of Dairy Science, vol. 90, no. 2, pp. 998-1007, 2007.

[14] L. Tao, "Oxidation of polyunsaturated fatty acids and its impact on food quality and human health," Advances in Food Technology and Nutritional Sciences, vol. 1, no. 6, pp. 135-142, 2015.

[15] R. Huang, E. Choe, and D. B. Min, "Kinetics for singlet oxygen formation by riboflavin photosensitization and the reaction between riboflavin and singlet oxygen," Journal of Food Science, vol. 69, no. 9, pp. C726-C732, 2004.

[16] S. Gonzalez, S. E. Duncan, S. F. O’Keefe, S. S. Sumner, and J. H. Herbein, "Oxidation and textural characteristics of butter and ice cream with modified fatty acid profiles," Journal of Dairy Science, vol. 86, no. 1, pp. 70-77, 2003.

[17] R. J. Baer, J. Ryali, D. J. Schingoethe et al., "Composition and properties of milk and butter from cows fed fish oil," Journal of Dairy Science, vol. 84, no. 2, pp. 345-353, 2001.

[18] F. Sansone, T. Mencherini, P. Picerno et al., "Microencapsulation by spray drying of Lannea microcarpa extract: technological 
characteristics and antioxidant activity," Journal of Pharmacy and Pharmacognosy Research, vol. 2, no. 4, pp. 100-109, 2014.

[19] A. Carrizzo, M. Ambrosio, A. Damato et al., "Morus alba extract modulates blood pressure homeostasis through eNOS signaling," Molecular Nutrition \& Food Research, vol. 60, no. 10, pp. 2304-2311, 2016.

[20] E. Sommella, G. Pepe, F. Pagano et al., "Detailed polyphenolic profiling of Annurca apple (M. pumila Miller cv Annurca) by a combination of RP-UHPLC and HILIC, both hyphenated to IT-TOF mass spectrometry," Food Research International, vol. 76, pp. 466-477, 2015.

[21] A. Formato, M. Gallo, D. Ianniello, D. Montesano, and D. Naviglio, "Supercritical fluid extraction of $\alpha$ - and $\beta$-acids from hops compared to cyclically pressurized solid-liquid extraction," The Journal of Supercritical Fluids, vol. 84, pp. 113-120, 2013.

[22] D. Montesano, O. Gennari, S. Seccia, and S. Albrizio, "A simple and selective analytical procedure for the extraction and quantification of lutein from tomato by-products by HPLCDAD," Food Analytical Methods, vol. 5, no. 4, pp. 710-715, 2012.

[23] P. Sivakumar, K. Anbarasu, and S. Renganathan, "Bio-diesel production by alkali catalyzed transesterification of dairy waste scum," Fuel, vol. 90, no. 1, pp. 147-151, 2011.

[24] G. Sivakumar, D. R. Vail, J. Xu et al., "Bioethanol and biodiesel: Alternative liquid fuels for future generations," Engineering in Life Sciences, vol. 10, no. 1, pp. 8-18, 2010.

[25] Y. Zhang, M. A. Dubé, D. D. McLean, and M. Kates, "Biodiesel production from waste cooking oil: 2 . Economic assessment and sensitivity analysis," Bioresource Technology, vol. 90, no. 3, pp. 229-240, 2003.

[26] AOAC International, Official Methods of Analysis, AOAC International, Gaithersburg, Md, USA, 16th edition, 2005.

[27] M. Stoytcheva, G. Montero, R. Zlatev, J. Á. León, and V. Gochev, "Analytical methods for lipases activity determination: A review," Current Analytical Chemistry, vol. 8, no. 3, pp. 400407, 2012.

[28] F. Hasan, A. A. Shah, and A. Hameed, "Methods for detection and characterization of lipases: A comprehensive review," Biotechnology Advances, vol. 27, no. 6, pp. 782-798, 2009.

[29] J. M. Evers, “The milkfat globule membrane-methodologies for measuring milkfat globule (membrane) damage," International Dairy Journal, vol. 14, no. 9, pp. 747-760, 2004.

[30] S. A. Lateef, N. Beneragama, T. Yamashiro, M. Iwasaki, C. Ying, and K. Umetsu, "Biohydrogen production from co-digestion of cow manure and waste milk under thermophilic temperature," Bioresource Technology, vol. 110, pp. 251-257, 2012.

[31] E. Lotero, Y. Liu, D. E. Lopez, K. Suwannakarn, D. A. Bruce, and J. G. Goodwin Jr., "Synthesis of biodiesel via acid catalysis," Industrial \& Engineering Chemistry Research, vol. 44, no. 14, pp. 5353-5363, 2005.

[32] J. M. Marchetti, V. U. Miguel, and A. F. Errazu, "Heterogeneous esterification of oil with high amount of free fatty acids," Fuel, vol. 86, no. 5-6, pp. 906-910, 2007.

[33] W. N. N. Wan Omar, N. Nordin, M. Mohamed, and N. A. S. Amin, "A two-step biodiesel production from waste cooking oil: Optimization of pre-treatment step," Journal of Applied Sciences, vol. 9, no. 17, pp. 3098-3103, 2009.

[34] Y. Wang, S. Ma, L. Wang, S. Tang, W. W. Riley, and M. J. T. Reaney, "Solid superacid catalyzed glycerol esterification of free fatty acids in waste cooking oil for biodiesel production," European Journal of Lipid Science and Technology, vol. 114, no. 3, pp. 315-324, 2012. 


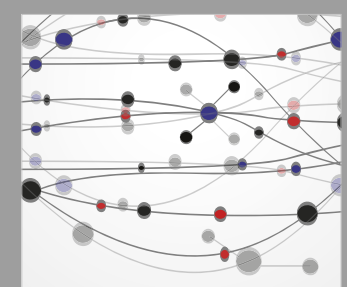

The Scientific World Journal
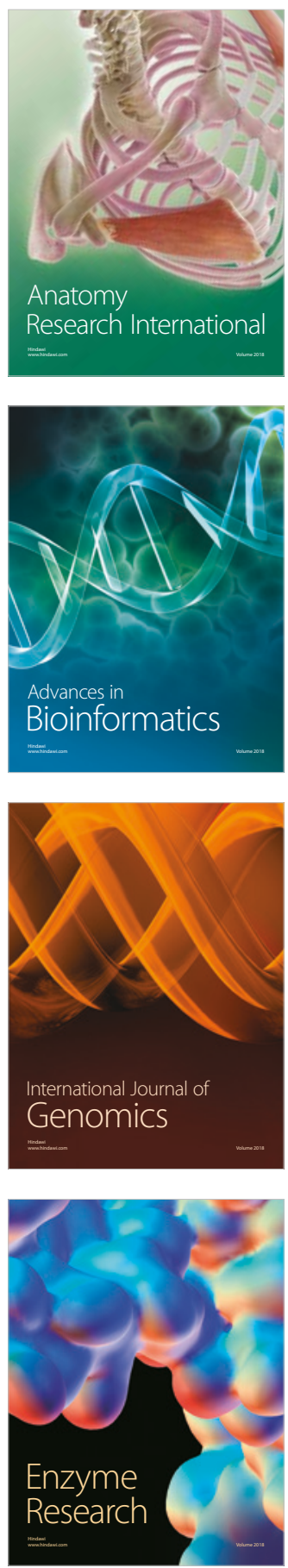
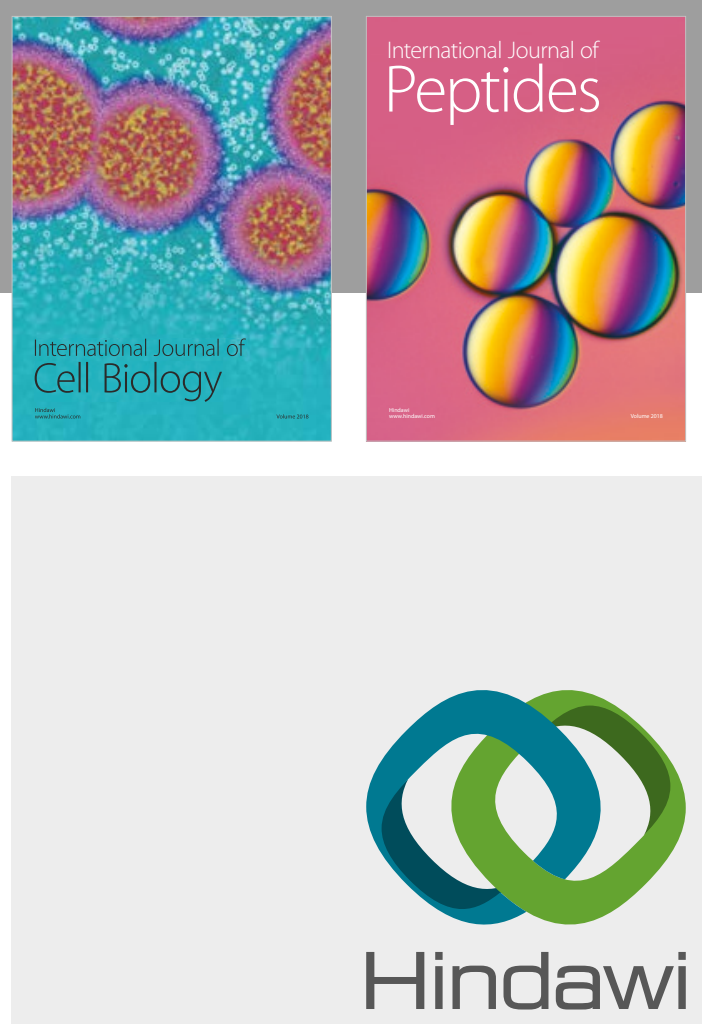

Submit your manuscripts at

www.hindawi.com
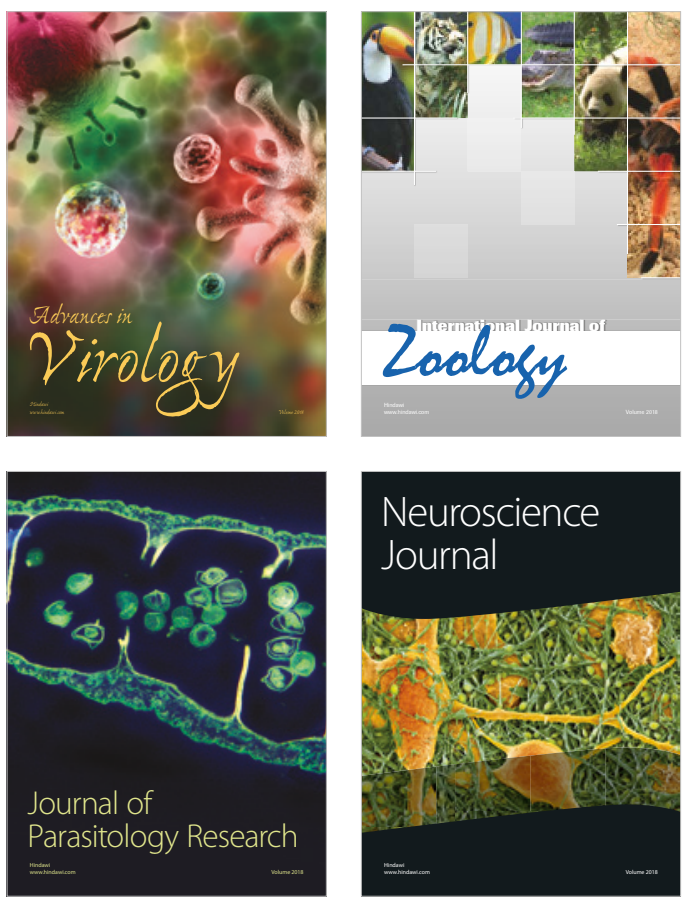
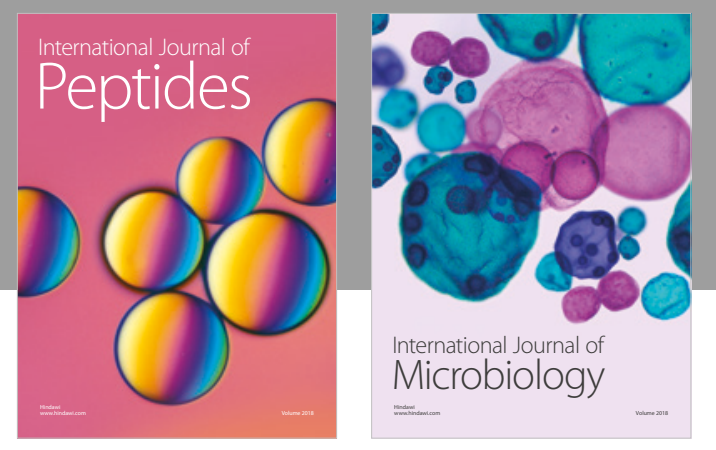

nternational Journal of Microbiology
Journal of
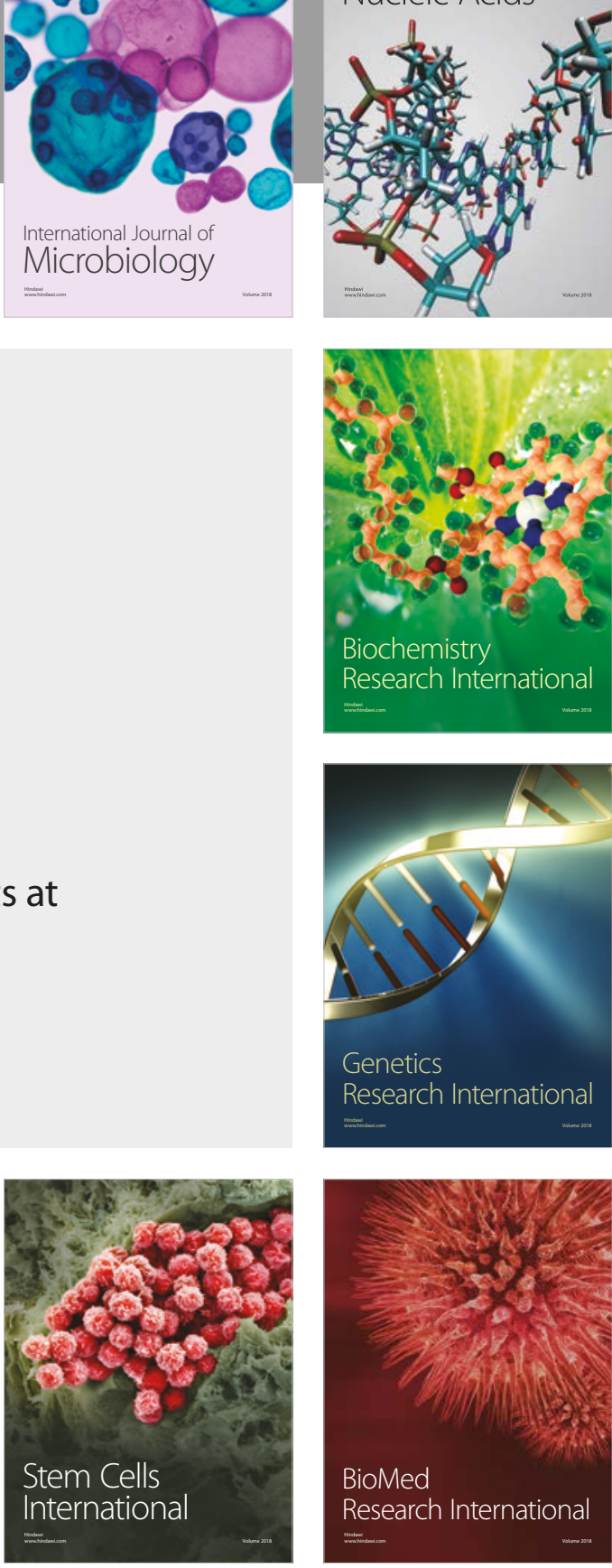
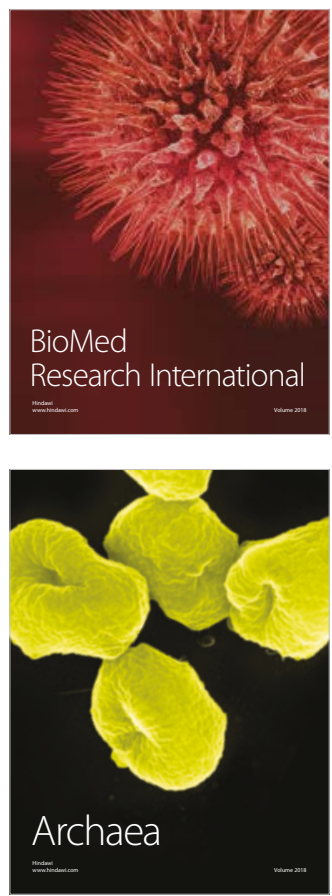